\title{
The abundance of Cryptosporidium and Giardia spp. in treated effluents produced by four wastewater treatment plants in the Gauteng Province of South Africa
}

\author{
M Dungeni and MNB Momba* \\ Environmental, Water and Earth Sciences Department, Tshwane University of Technology, Arcadia Campus, Private Bag X680, \\ Pretoria 0001, South Africa
}

\begin{abstract}
This study aimed at assessing the effectiveness of 4 wastewater treatment plants of the Gauteng Province, namely Zeekoegat, Baviaanspoort, Rayton and Refilwe Water Care Works (WCW), in the removal of Cryptosporidium and Giardia (oo)cysts. Wastewater influent and treated effluent samples were taken weekly between January and April 2008. Cryptosporidium and Giardia (oo)cysts were detected by immunofluorescence and immunomagnetic separation, according to a modified US EPA 1623 method. Effluent samples were subjected to a molecular study for the identification of Cryptosporidium parvum Genotype I and Giardia lamblia Assemblage A. The 18S rRNA gene for restriction digests was therefore used to characterise these (oo)cysts. Cryptosporidium oocysts were repeatedly detected in effluent samples collected from all wastewater treatments at lower concentration (range $<1$ to 40 oocysts/L) levels than Giardia cysts (range $<1$ to 175 cysts/ $\ell$ ). The mean removal efficiencies of Cryptosporidium and Giardia at the 4 wastewater treatment plants ranged from $67.40 \%$ to $98.26 \%$ and from $86.81 \%$ to $99.96 \%$, respectively. For all effluent samples, except Zeekoegat WCW, $29 \%$ and $41 \%$ contained oocysts of Cryptosporidium parvum Genotype I and cysts of Giardia lamblia Assemblage A, respectively. Both C. Parvum and G. lamblia are human pathogens. This stresses the potential risk of discharging these parasites into receiving water bodies.
\end{abstract}

Keywords: wastewater, removal, Cryptosporidium parvum, Giardia lamblia, genotype

\section{Introduction}

The world's freshwater reserves are limited and freshwater is obtained through the water cycle. The limited water reserves are declining year after year and freshwater is becoming a scarce commodity. Therefore, the recycling of treated wastewater is essential for reducing the negative impact of pollution on freshwater reserves. As South Africa is a water-scarce country, return flows (sewage and effluent purification) occupy second position in terms of the size of their contribution (14\%) to the total supply of freshwater in South Africa, with $77 \%$ sourced from surface water (dams and rivers) and $9 \%$ from groundwater (boreholes) (Van Vuuren, 2009).

Uncontrolled sewage discharges and poorly managed wastewater treatment plants have been identified as two of the major sources of water pollution in South Africa (Momba and Mfenyana, 2005; Momba and Sibewu, 2009). Treated sewage is often discharged directly into watercourses that also serve as sources of drinking water or which have recreational sites downstream. River water has been identified as a significant source of Cryptosporidium and other pathogens (Momba et al., 2006; Clarke et al., 2008; Pennil et al., 2008).

Parasites belonging to the genera Cryptosporidium and Giardia are an important and widespread cause of enteric diseases in humans and in many other vertebrates (WHO, 2004). The transmission of protozoan parasites occurs mainly through

\footnotetext{
* To whom all correspondence should be addressed.

푱 +27(82) 51373 95; fax: $+27(12) 3826354$; e-mail: mombamnb@tut.ac.za

Received 11 February 2010; accepted in revised form 9 June 2010.
}

the faecal-oral route by exposure to contaminated water and food (Rose et al., 2002). Several studies have shown that water is a source of various waterborne infectious diseases affecting numerous communities, particularly those in rural and indigenous areas (Venter, 2000; Murcott, 2006; Momba et al., 2008), and consequently an estimated 5 million people lose their lives due to water-related diseases each year (Pritchard et al., 2009; Baumgartner et al., 2007). Outbreaks of cryptosporidiosis in many communities in the past have been reported even when the bacterial quality of the water complied with the set standards after treatment (Insulander et al., 2005).

Giardiasis and cryptosporidiosis are common infections of domestic and wild animals, which shed a large number of cysts and oocysts into the environment (WHO, 2004). A study by Jarmy-Swan and co-workers on the prevalence of diarrhoeal disease caused by waterborne pathogens indicates that Cryptosporium and Giardia are endemic in the KwaZulu-Natal population, with prevalence rates of $39.3 \%$ in the $<1$-year age group and $38.5 \%$ in the 3- to 4-year age group (Jarmey-Swan et al., 2001). The occurrence of cryptosporidiosis and giardiasis is probably higher than recorded in this province. In 1998, Pegram and co-workers reported that only 1 in 14 people with diarrhoea in South Africa seeks formal treatment from a health practitioner, clinic or hospital every year, while approximately 43000 South Africans have been estimated to die from diarrhoea every year. Thus, producing effluent of a high microbiological quality remains a matter of great concern in developing countries such as South Africa.

It has been reported that bacteria such as E. coli, Salmonella typhimurium and Vibrio cholera and viral indicators, once entrapped in suspended flocs, appeared to be able to survive in the effluent despite high residual chlorine 
concentrations. However, the removal of these microorganisms by sedimentation and filtration is a major prerequisite for plants that have demonstrated successful disinfection efficiency (Momba et al., 2006).

A serious concern is that the receiving waterbodies, which can also be contaminated with pathogenic protozoa, are used by communities for drinking, recreational and agricultural purposes directly or indirectly without prior treatment. The (oo)cysts are insensitive to disinfectants at concentrations commonly used in water treatment plants to reduce bacterial contamination (Mahdy et al., 2007). As the recent study revealed the failure of South African wastewater treatment plants to remove pathogenic bacteria and viral indicators, it was also crucial to assess the effectiveness of Zeekoegat, Baviaanspoort Rayton and Refilwe wastewater treatment plants in the removal of Cryptosporidium and Giardia (oo)cysts from their influents. Monitoring the quality of wastewater effluents before their discharge into the receiving water body might therefore assist water services providers in tracing the origin of water source contaminations which can result in a diarrhoeal epidemic in the Gauteng Province.

\section{Materials and methods}

\section{Study sites}

The study was conducted at 4 wastewater treatment plants in the Gauteng Province of South Africa. All these plants treat municipal wastewaters using the activated sludge system. Zeekoegat and Baviaanspoort water care works (WCW) are 2 of several wastewater treatment plants that serve the City of Tshwane Metropolitan Municipality (hereafter referred to simply as Tshwane). Both plants are located approximately $40 \mathrm{~km}$ east of Pretoria (which forms part of the Tshwane municipal area). These 2 plants were studied because they drain into the Roodeplaat Dam, which serves as a source of water for several drinking water treatment plants in the area. It is also a recreational area.

The Zeekoegat WCW is located immediately to the west of Roodeplaat Dam. This plant has a design capacity of 35 $\mathrm{M} \ell /$ day, which is upgradeable to $120 \mathrm{M}$ /day. At the Zeekoegat WCW, the influent flows into primary settling tanks and then to a division tank that enables the process controllers to maintain a constant flow rate to the 2 biological reactors despite changes in influent flow rates. The biological reactors are characterised by automated submerged diffusion-air aeration systems. The effluent from the biological reactors flows to the secondary settling tanks where clarification takes place. The overflow from the settlers flows through sand filters and finally to an emergency dam where a prolonged contact time with chlorine is achieved . The treated effluent flows into the Roodeplaat Dam via a short earth canal that passes through the Roodeplaat Dam Nature Reserve.

Baviaanspoort WCW has a capacity of approximately 35 $\mathrm{M} \ell /$ day. The set-up of Baviaanspoort WCW is similar to that of Zeekoegat WCW. The main difference is in the design of the plant, which is characterised by the lack of a division tank, the presence of a mechanical aeration system in the 2 biological reactors and the absence of sand filtration of the final treated effluent. This plant is located $10 \mathrm{~km}$ upstream of the Roodeplaat Dam on the eastern bank of the Pienaars River.

The Rayton and Refilwe WCWs are located in the small towns of Rayton and Cullinan, respectively, and serve their respective towns. These towns are also approximately $45 \mathrm{~km}$ east of Pretoria. The populations, according to the Statistics South Africa 2001 census of Cullinan and Rayton, were 7683 and 2 961, respectively (STATS SA, 2001). The design of these plants is simpler than those of the first 2 plants. The influent flows through a grit screen and then into a single biological reactor tank. The effluent of the biological reactor flows to the settling tank and the overflow of the settler flows to the contact tank. After the contact tank, no further treatment is done. The effluent is discharged into the receiving water bodies. The design capacities of the Rayton and Refilwe WCWs are 0.6 and $1.1 \mathrm{M} \ell /$ day, respectively. Because of their small size, they were included in this study to compare their performance with that of the larger plants.

\section{Sample collection and preparation}

Samples of untreated wastewater influents $(2 \ell)$ and treated wastewater final effluents $(10 \ell)$ were collected weekly between January and April 2008. The water samples were filtered through a $300 \mu \mathrm{m} 50$-mesh sieve to remove large particles and then concentrated by filtration on cellulose-acetate filters of $0.8 \mu \mathrm{m}$ pore size and $142 \mathrm{~mm}$ diameter (Sartorius, RSA). The filters were scraped and washed using $50 \mathrm{ml} 0.1 \%$ Tween 80 followed by centrifugation at $2000 \mathrm{x} g$ to pellet the (oo)cysts. The supernatants were aspirated to $10 \mathrm{~m} \ell$ above the pellet according to the US EPA 1623 method (US EPA, 2001).

\section{Immunomagnetic separation and staining}

The cysts and oocysts were captured from the remaining $10 \mathrm{~m} \ell$ of the supernatant using Dynalbead anti-Giardia and anti-Cryptosporidium immunomagnetic antibodies (DEHTEQ, RSA). A $50 \mu \ell$ aliquot of the purified suspension containing the captured oocysts was air-dried on a well-slide and stained with anti-G. lamblia and anti-C. parvum monoclonal antibodies conjugated to fluorescein isothiocyanate (FITC) (Aqua-Glo $\mathrm{G} / \mathrm{C}$ Kit, Invitrogen USA). The slides were examined at $1000 \mathrm{x}$ magnification using an Axio Carl Zeiss epifluorescence microscope (Carl Ziess, RSA). Giardia cysts were identified based on their size, shape, and the pattern and intensity of immunofluorescent assay staining (bright green fluorescence of the cyst wall). Cryptosporidium oocysts were identified based on their size, shape, and the presence of a suture on the oocyst wall at $1000 \mathrm{x}$ magnification. The number of (oo)cysts was counted in duplicate for each sample according to the US EPA 1623 method (2001).

\section{DNA extraction and PCR amplification}

The polymerase chain reaction (PCR) was used to confirm the identities of the presumptive oocysts. DNA extraction was performed according to the method of Sturbaum and co-workers (2001). A $50 \mu \ell$ suspension was incubated with $1 \mathrm{mg}$ of proteinase $\mathrm{K}$ per $\mathrm{m} \ell$ at $56^{\circ} \mathrm{C}$ for at least $1 \mathrm{~h}$ and subjected to 6 freeze-thaw cycles ( $2 \mathrm{~min}$ in liquid nitrogen, followed by $2 \mathrm{~min}$ in a $98^{\circ} \mathrm{C}$ water bath), with the centrifugation (16000 $\mathrm{x} g$ ) performed between the third and fourth cycles for $30 \mathrm{~s}$. Lastly, the $30 \mu \ell$ suspension was centrifuged at $16000 \mathrm{x} g$ for $3 \mathrm{~min}$. One $10 \mu \ell$ aliquot of the freeze-thaw supernatant was used directly as the PCR DNA template.

The PCR primers and conditions used in this study for Cryptosporidium and Giardia have been fully described by Sturbaum et al. (2001) and Cacció (2003) (Table 1). The nested PCR primers for C. parvum amplified a 
Table 1

PCR primer base sequences and targeted amplicon size of Cryptosporidium and Giardia

\begin{tabular}{|c|c|c|c|c|}
\hline Target organism & $\begin{array}{l}\text { Primers } \\
\text { name }\end{array}$ & Sequence 5'-3' & Target & References \\
\hline C. parvum & \begin{tabular}{|l|} 
ExCry 1 \\
ExCry 2 \\
NesCry 3 \\
NesCry 4 \\
\end{tabular} & $\begin{array}{l}\text { GCC AGT AGT CAT ATG CTT GTC TC } \\
\text { ACT GTT AAA TAG AAA TGC CCC C } \\
\text { GCG AAA AAA CTC GAC TTT ATG GAA GGG } \\
\text { GGA GTA TTC AAG GCA TAT GCC TGC } \\
\end{array}$ & $\begin{array}{l}\text { 590-bp of } 18 \mathrm{~S} \\
\text { rRNA }\end{array}$ & $\begin{array}{l}\text { Sturbaum et al., (2001) } \\
\text { Reed et al., (2001) }\end{array}$ \\
\hline G. lamblia & $\begin{array}{l}\text { G7 } \\
\text { G759 }\end{array}$ & $\begin{array}{l}\text { AAG CCC GAC GAC CTC ACC CGC AGT GC } \\
\text { GAG GCC GCC CTG GAT CTT CGA GAC GAC }\end{array}$ & $\begin{array}{l}\text { 753-bp of } \\
\text { B-giardin gene }\end{array}$ & Cacciò et al., (2003) \\
\hline
\end{tabular}

Table 2

Restriction enzymes used to subtype the Cryptosporidial and Giardial PCR products

\begin{tabular}{|c|c|c|c|c|}
\hline $\begin{array}{l}\text { Restriction } \\
\text { enzyme }\end{array}$ & Target organism & Conditions & Products & Reference \\
\hline \begin{tabular}{l|l}
$V_{s p \mathrm{I}}$ & \\
\end{tabular} & C. parvum genotype 1 and II & \multirow{2}{*}{$\begin{array}{l}\text { In } 20-\mu \ell \text { reaction volumes, } \\
15 \mu \ell \text { of amplicon is } \\
\text { digested with } 5 \mathrm{U} \text { of } V s p I \text { or } \\
4 \mathrm{U} \text { of } D r a \mathrm{II} \text { for } 6 \text { h at } 37^{\circ} \mathrm{C}\end{array}$} & \multirow[t]{2}{*}{$\begin{array}{l}\text { Digestion of } 590 \text { bp product for } \\
\text { only genotype I. }\end{array}$} & \multirow[t]{2}{*}{$\begin{array}{l}\text { Sturbaum et al., } 2001 \\
\text { Reed et al., } 2001\end{array}$} \\
\hline DraII & C. baileyi and C. serpentis & & & \\
\hline HaeIII & $\begin{array}{l}\text { Giardia lamblia Assemblage } \\
\mathrm{A} \text { and B }\end{array}$ & $\begin{array}{l}4 \mathrm{~h} \text { digestion at } 37^{\circ} \mathrm{C} \text { with } \\
10 \mathrm{U} \text { of HaeIII in a final } \\
\text { volume of } 20 \mu \ell .\end{array}$ & $\begin{array}{l}\text { Fragments of } 202,201,150, \\
126, \text { and } 74 \text { bp for Assemblage } \\
\text { A, and fragments of } 202,176, \\
150,117,84, \text { and } 24 \text { bp for } \\
\text { Assemblage B }\end{array}$ & $\begin{array}{l}\text { Cacciò et al., } 2003 \\
\text { Cacciò et al., } 2002\end{array}$ \\
\hline
\end{tabular}

590-bp region of the $18 \mathrm{~S}$ rRNA gene of Genotype I and II. An initial denaturation step was performed at $95^{\circ} \mathrm{C}$ for $5 \mathrm{~min}$ and a 10 min holding step at $80^{\circ} \mathrm{C}$; this was followed by 40 cycles at $94^{\circ} \mathrm{C}$ for $45 \mathrm{~s}, 53^{\circ} \mathrm{C}$ for $1 \mathrm{~min} 16 \mathrm{~s}$, and $72^{\circ} \mathrm{C}$ for $45 \mathrm{~s}$. Final extension was carried out at $72^{\circ} \mathrm{C}$ for $7 \mathrm{~min}$. The nestedreaction parameters were the same except that the 35 cycles were performed at an annealing temperature of $65^{\circ} \mathrm{C}$ and denaturation, annealing, and extension time periods were $25 \mathrm{~s}$ each. (Sturbaum et al., 2001). The PCR primers for G. lamblia amplified a 753-bp region of the $\beta$-giardin gene of Assemblage A and B. An initial denaturation of $5 \mathrm{~min}$ at $94^{\circ} \mathrm{C}$ was used, followed by a set of 35 to 40 cycles, each consisting of $30 \mathrm{~s}$ at $94^{\circ} \mathrm{C}, 30 \mathrm{~s}$ at $65^{\circ} \mathrm{C}$, and $1 \mathrm{~min}$ at $72^{\circ} \mathrm{C}$. A final extension of 5 min at $72^{\circ} \mathrm{C}$ was performed (Cacciò et al., 2003). The PCR reactions were performed in a Chromo 4 thermal cycler (BIORAD, RSA). Following PCR, $15 \mu \ell$ of the Cryptosporidium nested amplicon was digested with $5 \mathrm{U}$ of $V s p \mathrm{I}$ (Promega) for $6 \mathrm{~h}$ at $37^{\circ} \mathrm{C}$ (Table 2) (Sturbaum et al., 2001). Similarly, the Giardia PCR products were treated with $10 \mathrm{U}$ of HaeIII (Promega) for $4 \mathrm{~h}$ at $37^{\circ} \mathrm{C}$ as shown in Table 2 (Cacciò et al., 2002; 2003). The digested products were visualised on $2 \%$ agarose gels stained with ethidium bromide $(0.5 \mu \mathrm{g} / \mu \ell)$.

\section{Statistical analysis}

To show the efficiency of the 4 wastewater treatment plants in removing pathogenic protozoa, the data were analysed statistically using the SPSS computer software, Version 11.0. A descriptive analysis was performed with interest in the kurtosis and skewness of the data. With $75 \%$ of the kurtosis and skewness between -2 and +2 , the data proved to be of normal distribution hence parametric tests, which have assumptions of normality, such as comparison of means using the one-way analysis of variance (ANOVA) and test of relationship were carried out using the Pearson correlation index at 95\% confidence interval.

\section{Results}

In general, Cryptosporidium oocysts and Giardia cysts were detected in influents and effluents from all the plants during the study period. Compared to the counts of Giardia cysts, lower counts for Cryptosporidium oocysts were observed in both the influent and effluent samples. While these parasites were always present in the effluents collected from the Refilwe WCW, they could also be detected from time to time at the Baviaanspoort, Zeekoegat and Rayton WCWs.

Table 3 summarises the number of oocysts and cysts detected from influent and effluent samples of the Zeekoegat and Baviaanspoort WCWs. At the Zeekoegat WCW, the counts of oocysts ranged between 0 and 150 oocysts/ $\ell$ in the influents and between 0 and 2 oocysts/ $\ell$ in the effluent samples. In the same plant, the counts for cysts ranged between 0 and $4500 \mathrm{cysts} / \ell$ in the influents and between 0 and 1 cysts $/ \ell$ in the effluents. Cryptosporidium oocysts were isolated in $50 \%$ of the influent samples and in $43 \%$ of the effluent samples, while Giardia was observed in $78 \%$ of all influent samples and $36 \%$ of effluent samples (Table 3). At the Baviaanspoort WCW, the counts of oocysts ranged between 0 and 76 oocysts/ $\ell$ in the influent samples and between 0 and 35 oocysts/ $\ell$ in the effluent samples. For the same plant, the cyst counts ranged between 0 and $4300 \mathrm{cysts} / \ell$ in the influents and between 0 and $27 \mathrm{cysts} / \ell$ in the effluent samples. In this plant, Cryptosporidium occurred in $57 \%$ of the influent samples and in $62 \%$ of the effluent samples, while Giardia was observed in $93 \%$ of all influent samples and $86 \%$ of effluent samples (Table 3).

The number of oocysts and cysts observed per litre in the influent and effluent samples collected at the Rayton and Refilwe WCWs is shown in Table 4. At the Rayton WCW, the counts of oocysts ranged between 0 and 130 oocysts $/ \ell$ in the influents and between 0 and 15 oocysts/ $\ell$ in the effluent samples. The cyst counts for the same plant ranged between 0 and 210 cysts $/ \ell$ in the influents and between 0 and 24 cysts $/ \ell$ in the effluents. Cryptosporidium oocysts were observed in 57\% of 


\begin{tabular}{|c|c|c|c|c|c|c|c|c|}
\hline \multicolumn{9}{|c|}{$\begin{array}{c}\text { Table } 3 \\
\begin{array}{c}\text { The number of oocysts and cysts observed per litre of sample collected from the influent and } \\
\text { effluent of Zeekoegat and Baviaanspoort wastewater treatment plants. }\end{array}\end{array}$} \\
\hline \multirow[t]{3}{*}{ Date in 2008} & \multicolumn{4}{|c|}{ Zeekoegat } & \multicolumn{4}{|c|}{ Baviaanspoort } \\
\hline & \multicolumn{2}{|c|}{ Influent } & \multicolumn{2}{|c|}{ Effluent } & \multicolumn{2}{|c|}{ Influent } & \multicolumn{2}{|c|}{ Effluent } \\
\hline & Oocysts & Cysts & Oocysts & Cysts & Oocysts & Cysts & Oocysts & Cysts \\
\hline 29 Jan & 145 & 450 & 2 & 1 & 42 & 3400 & 10 & 10 \\
\hline $7 \mathrm{Feb}$ & 0 & 123 & 0 & 0 & 0 & 3200 & 0 & 15 \\
\hline $13 \mathrm{Feb}$ & 58 & 450 & 0 & 0 & 45 & 2400 & 12 & 0 \\
\hline $20 \mathrm{Feb}$ & 46 & 25 & 1 & 1 & 0 & 4300 & 13 & 12 \\
\hline $27 \mathrm{Feb}$ & 0 & 0 & 0 & 0 & 51 & 820 & 12 & 13 \\
\hline $5 \mathrm{Mar}$ & 0 & 45 & 1 & 0 & 0 & 560 & 0 & 0 \\
\hline $12 \mathrm{Mar}$ & 48 & 2100 & 0 & 1 & 26 & 1200 & 0 & 2 \\
\hline 19 Mar & 0 & 0 & 0 & 1 & 0 & 4200 & 0 & 4 \\
\hline $26 \mathrm{Mar}$ & 53 & 510 & 2 & 0 & 0 & 3100 & 2 & 16 \\
\hline $2 \mathrm{Apr}$ & 0 & 0 & 0 & 1 & 76 & 570 & 10 & 1 \\
\hline $11 \mathrm{Apr}$ & 16 & 4500 & 2 & 0 & 0 & 0 & 6 & 4 \\
\hline $16 \mathrm{Apr}$ & 0 & 3200 & 1 & 0 & 45 & 1500 & 35 & 5 \\
\hline $23 \mathrm{Apr}$ & 150 & 15 & 0 & 0 & 10 & 43 & 0 & 27 \\
\hline $30 \mathrm{Apr}$ & 0 & 7 & 0 & 0 & 67 & 163 & 1 & 9 \\
\hline Mean & 37 & 816 & 1 & 0 & 26 & 1818 & 7 & 8 \\
\hline Removal efficiency (\%) & & & 98.26 & 99.96 & & & 67.40 & 99.60 \\
\hline
\end{tabular}

\begin{tabular}{|c|c|c|c|c|c|c|c|c|}
\hline \multicolumn{9}{|c|}{$\begin{array}{c}\text { Table } 4 \\
\begin{array}{c}\text { The number of oocysts and cysts observed per litre of sample collected from the influent and } \\
\text { effluent of Rayton and Refilwe wastewater treatment plants. }\end{array}\end{array}$} \\
\hline \multirow[t]{3}{*}{ Date in 2008} & \multicolumn{4}{|c|}{ Rayton } & \multicolumn{4}{|c|}{ Refilwe } \\
\hline & \multicolumn{2}{|c|}{ Influent } & \multicolumn{2}{|c|}{ Effluent } & \multicolumn{2}{|c|}{ Influent } & \multicolumn{2}{|c|}{ Effluent } \\
\hline & Oocysts & Cysts & Oocysts & Cysts & Oocysts & Cysts & Oocysts & Cysts \\
\hline 29 Jan & 5 & 120 & 2 & 24 & 74 & 130 & 12 & 26 \\
\hline $7 \mathrm{Feb}$ & 43 & 3 & 3 & 3 & 46 & 410 & 9 & 35 \\
\hline $13 \mathrm{Feb}$ & 0 & 57 & 5 & 18 & 53 & 2900 & 13 & 52 \\
\hline $20 \mathrm{Feb}$ & 48 & 0 & 0 & 0 & 0 & 370 & 1 & 26 \\
\hline $27 \mathrm{Feb}$ & 41 & 0 & 3 & 0 & 54 & 150 & 11 & 41 \\
\hline 5 Mar & 0 & 63 & 2 & 12 & 42 & 400 & 25 & 11 \\
\hline $12 \mathrm{Mar}$ & 0 & 150 & 6 & 0 & 0 & 2300 & 40 & 35 \\
\hline 19 Mar & 130 & 0 & 4 & 13 & 101 & 0 & 12 & 31 \\
\hline 26 Mar & 0 & 210 & 0 & 0 & 52 & 520 & 0 & 3 \\
\hline $2 \mathrm{Apr}$ & 0 & 0 & 1 & 2 & 46 & 1200 & 24 & 175 \\
\hline $11 \mathrm{Apr}$ & 17 & 0 & 5 & 0 & 0 & 46 & 0 & 15 \\
\hline $16 \mathrm{Apr}$ & 5 & 45 & 0 & 6 & 86 & 45 & 2 & 4 \\
\hline $23 \mathrm{Apr}$ & 2 & 3 & 15 & 8 & 53 & 2 & 23 & 7 \\
\hline $30 \mathrm{Apr}$ & 0 & 1 & 2 & 0 & 1 & 16 & 5 & 33 \\
\hline Mean & 21 & 47 & 3 & 6 & 43 & 606 & 13 & 35 \\
\hline Removal efficiency (\%) & & & 83.51 & 86.81 & & & 70.89 & 94.18 \\
\hline
\end{tabular}

the influent samples and in $79 \%$ of the effluent samples, while Giardia cysts were observed in $64 \%$ of the influent samples and $57 \%$ of the effluent samples. At the Refilwe WCW, the counts of oocysts ranged between 0 and 101 oocysts/ $\ell$ in the influent samples and between 0 and 40 oocysts/ $\ell$ in the effluent samples. In the same plant, the counts for cysts ranged between 0 and 2900 cysts/ $\ell$ in the influent samples and between 3 and 175 cysts/ $\ell$ in the effluent samples. Cryptosporidium oocysts were observed in $79 \%$ of the influent samples and in $86 \%$ of the effluent sample, whilst Giardia cysts were observed in $93 \%$ of all influent samples and in all of the effluent samples (Table 4).

Comparing the larger plants (Zeekoegat and Baviaanspoort) with the smaller plants (Refilwe and Rayton), it was noted that there was no significant differences in the number of oocysts and cysts isolated from the influent samples $(p \geq 0.05)$. However, with respect to the number of cysts in the influents and effluents, the Zeekoegat WCW had significantly lower counts than the Baviaanspoort WCW $(p \leq 0.05)$. Significant differences 


\begin{tabular}{|l|c|c|c|c|}
\hline \multicolumn{5}{|c|}{ Positive detection of subtypes in effluent samples } \\
\hline \multirow{2}{*}{ Plant } & Cryptosporidium parvum & \multicolumn{2}{c|}{ Giardia lamblia } \\
\cline { 2 - 5 } & Genotype 1 & Genotype II & Assemblage A & Assemblage B \\
\hline Baviaanspoort & $4 / 14(29 \%)$ & $3 / 14(22 \%)$ & $5 / 14(36 \%)$ & $1 / 14(7 \%)$ \\
\hline Zeekoegat & 0 & 0 & 0 & 0 \\
\hline Rayton & $1 / 14(7 \%)$ & 0 & $4 / 14(29 \%)$ & $2 / 14(14 \%)$ \\
\hline Refilwe & $7 / 14(50 \%)$ & $4 / 14(29 \%)$ & $9 / 14(62 \%)$ & $8 / 14(57 \%)$ \\
\hline
\end{tabular}

in the number of oocysts and cysts isolated from the effluent samples $(p \leq 0.05)$ were also noted between the Rayton and Refilwe WCWs. The counts for Cryptosporidium oocysts at the Refilwe WCW's effluents were found to be significantly higher $(p \leq 0.05)$ than those of Baviaanspoort and Zeekoegat. Furthermore, it was observed that the counts of Giardia cysts in the effluent samples of the Refilwe WCW were significantly higher $(p \leq 0.05)$ than those at the rest of the plants.

With the exception of the effluent samples collected from the Zeekoegat WCW, which showed the absence of the targeted genotypes of the parasites from all samples collected during the study period, the PCR reactions resulted in the positive identification of Cryptosporidium parvum Genotype I and Giardia lamblia Assemblage A at $29 \%$ and $36 \%$ for Baviaanspoort WCW, $7 \%$ and $29 \%$ for Rayton WRC, and $50 \%$ and $62 \%$ for Refilwe WCW, respectively (Table 5). Overall, pathogens capable of interspecies infection, Cryptosporidium parvum Genotype II and Giardia lamblia Assemblage B, were observed at lower occurrences than those that are infectious to humans only (Table 5).

\section{Discussion}

The transmission of Giardia and Cryptosporidium spp. through contaminated water, food and mainly the oral-faecal route to humans is well documented. The cycling of these pathogens can be between humans and also between animals and humans (Thompson, 2000; Cacció et al., 2003). Because the infected individuals pass very large numbers of oocysts and cysts with their feaces, this increases the environmental contamination. The situation is worsened by the fact that these pathogens can withstand normal water disinfection processes. The results of this study revealed that Giardia cysts were ubiquitous in the influents collected from Zeekoegat, Baviaanspoort, Rayton and Refilwe WCWs, whereas Cryptosporidium oocysts occurred less frequently. Similar occurrences of cysts and oocysts were reported by previous investigators (Brandonisio et al., 2000; Cacciò et al., 2003). Even after the treatment of the influents, the (oo)cysts were still found in considerable concentrations in the final effluents of the Baviaanspoort, Rayton and Refilwe WCWs, as indicated in Tables 3 and 4. Despite the high removal efficiencies of Cryptosporidium and Giardia recorded at the Zeekoegat, Baviaanspoort, Rayton and Refilwe WCWs during the study period (Tables 3 and 4), the collective range of (oo)cysts detected in final effluents discharged into the receiving water bodies ranged from $<1$ to 215 cysts $/ \ell$. The highest removal of oocysts and cysts $(98.36 \%$ and $99.96 \%$, respectively) noted at the Zeekoegat WCW could be attributed to the presence of the rapid sand filtration process, which resulted in the physical removal of the protozoan parasites from the water, as the operational chlorine disinfection dosing levels (between 1.5 and $2.0 \mathrm{mg} / \ell$ ) employed in all plants are considered ineffective for inactivating oocysts and cysts (Clancy et al., 2004).
The findings of the present study concur with those obtained by Casson and co-workers (1990) and Robertson and co-workers (2000). Casson and co-workers indicated that primary settlement had an (oo)cyst removal efficiency of between 0 and $53 \%$ at one wastewater plant. Robertson and co-workers (2000) estimated the removal efficiency of Giardia cysts to range between 60 and $90 \%$ in wastewater treatment plants incorporating a primary and secondary process, and removal efficiency varied from under $10 \%$ to over $90 \%$ for Cryptosporidium oocysts. A comparison of these 2 studies demonstrated that secondary treatments were of more importance in removal of these parasites than primary settlement.

Using the US E P A Method 1623, Castro-Hermida and co-workers (2008) also found both parasites in influent and effluent samples from 12 Galicia (northwest Spain) wastewater treatment plants throughout the year, and Giardia cysts $(G$. duodenalis) always outnumbered Cryptosporidium spp. The authors indicated that the mean concentration of Giardia cysts per litre of influent/effluent was significantly higher $(p<0.05)$ than the mean concentration of Cryptosporidium spp. per litre of influent/effluent. Similar observations were also noted in the present study (Tables 3 and 4). These findings, therefore, confirm the sensitivity level of US EPA Method 1623 in the detection of Cryptosporidium oocysts and species, and Giardia cysts, in wastewater sources.

Giardia cysts and Cryptosporidium oocysts have been found in a number of different waters and in treated drinking water in South Africa, and are commonly found in surface waters. In a study conducted in the former Natal and Transvaal provinces over a period of 3 years (1992-1994), samples were taken from raw sewage, treated effluents, surface water and drinking water. All of the samples collected from 10 surface water sites were contaminated with Giardia cysts and Cryptosporidium oocysts at levels ranging between 50 and 1000 counts/100 (Gericke et al., 1995). The authors also indicated that conventional wastewater treatment works could not significantly reduce cyst or oocyst numbers, from raw wastewater to treated effluents discharged in the receiving water body (Gericke et al., 1995). These findings corroborate with those of the present investigation in terms of (oo)cyst removal, especially by Refilwe, Rayton and Baviaanspoort WCWs. Since 1995, Stellenbosch Municipality had been testing quarterly for parasites at the town's 3 untreated raw water sources. The presence of both Giardia cysts and Cryptosporidium oocysts was detected for the first time in March 1998 (Mackintosh et al., 2000).

Giardia cysts and Cryptosporidium oocysts are extremely resistant to environmental stress and to treatment and are minimally affected by chlorination, as stated above. They may also survive for days or months in the environmental water, and animals may act as reservoirs of infection (DWAF, 1996). This clearly explained their persistence in the effluents collected from the Refilwe WCW, while these parasites could 
be detected from time to time at other plants, especially at the Baviaanspoort and Rayton WCWs. In some cases, their absence or lower counts in the influents were coupled with higher counts in the effluents (Tables 3 and 4). This demonstrated the ability of the (oo)cysts to survive for days or months in the environmental water even after their discharge into receiving water bodies.

The infective dose for Cryptosporidium and Giardia is as low as 1 cyst or oocyst, which is quite sufficient to cause infection (DWAF, 1996; Cacció et al., 2003). As the amount of (oo)cysts isolated from the effluents produced by the 4 wastewater treatment plants under this study was greater than 1 per litre (Tables 3 and 4), there might be a risk of protozoan parasite infection for continuous, short or occasional exposures to these water sources. The microbiological quality of the effluents discharged by all these plants is therefore a matter of concern, especially for the surrounding communities who use these water sources, including their respective receiving water bodies, for drinking, recreational and agricultural purposes. Consequently, more consideration should be given to the management of the drinking water plants in order to comply with the suggested safe levels of less than 1 (oo)cyst/ $\ell$, as set nationally by water services authorities (DWAF, 1996).

Immunomagnetic separation-based epifluorescence microscopy, a conventional diagnostic method, is capable of identifying the genera Cryptosporidium and Giardia based on morphological features. However this technique does not allow a reliable identification of species. Hence, the identification of genotypes requires the use of molecular assays. The most widely-used markers (the small subunit ribosomal DNA and a set of nuclear genes) enable the 2 major subtypes in the $C$. parvum and G. lamblia species to be distinguished. This is possible through the selection of sequences that display a higher level of polymorphism, as proved by previous investigators (Johnson et al., 1995; Spano et al., 1997, Cacció et al., 2003). Therefore, in this study, the occurrence of Cryptosporidium and Giardia (oo)cysts in wastewater treatment plants was investigated up to the species subtype level. This is of importance, given that G. lamblia and C. parvum are associated with both animal and human infections (Cacció et al., 2002; 2003).

The most commonly identified etiological agents of human cryptosporidiosis and giardiasis have been Cryptosporidium parvum and G. lamblia. Based on the molecular characterisation of oocysts and cysts, these parasites can be divided into 2 groups of genetically distinct subtypes: $C$. parvum Genotype I and G. lamblia Assemblage A. These 2 groups are associated wholly with human infection while Genotype II and Assemblage B are linked to both human and animal infections (Xiao et al., 2000). During the study period it was noted that the Refilwe WCW discharged significantly higher loads of oocysts and cysts per litre compared to other wastewater treatment plants. This was confirmed at a molecular level, which resulted in the identification of C. Parvum Genotype I and G. lamblia Assemblage A in 50\% and 62\%, respectively, of samples collected from this plant. The molecular study also revealed the presence of $C$. parvum Genotype II and G. lamblia Assemblage B in 29\% and 57\%, respectively, of the effluent samples taken from this plant. Although viability studies on oocysts and cysts and epidemiological studies in the community served by this plant were not carried out, these findings indicate that the effluents processed at this wastewater treatment plant could be a potential source of human infection with C. parvum and G. lamblia. No species identification was possible for samples taken from the effluents of Zeekoegat WCW.
This could be due to the fact that the (oo)cysts, as suggested by observation through immunomagnetic methods, could be of a different subspecies, and thus amplification could not be achieved with the primers used in this study (Cacció et al., 2003; Sturbaum et al., 2001). In view of this observation, the presence of oocysts and cysts, in the absence of species data, does not imply a risk of transmission of protozoan parasites of this genera that are of health risk to humans. In general, this study revealed that the risk of contamination of water courses by Cryptosporidium ssp. and Giardia spp. is considerable. It is important that wastewater treatment authorities consider the relevance of the levels of contamination by both parasites in wastewater, and develop adequate countermeasures.

\section{Conclusions and recommendations}

The results of this study provide insight into wastewater treatment plants as a source of pollution of rivers with respect to Cryptosporidium and Giardia species and also highlight the potential health risk associated with the use of the effluents or the receiving water bodies for drinking, recreational and agricultural purposes. Despite the high removal efficiencies of these protozoan parasites demonstrated by all of the wastewater treatment plants sampled, the results of this study revealed that Cryptosporidium and Giardia persisted in the effluents collected from the Refilwe WCW. At the other plants, especially the Baviaanspoort and Rayton WCWs, these parasites could also be detected from time to time. In other cases, their absence in the influents and presence in the effluents, or lower counts in the influents coupled with higher counts in the effluents, was noted. This demonstrated the ability of the (oo)cysts to survive for days or months in the environmental water even after their discharge into the receiving water bodies.

The study also revealed that the high removal efficiency of Cryptosporidium and Giardia noted in Zeekeogat WCW was linked to the physical process incorporated into this plant To curb disease outbreaks related to Cryptosporidium and Giardia, this study therefore suggests an upgrading of the wastwater treatment plants by including processes such as sand filters and UV light disinfection, which have proved to be effective in the removal and inactivation of these protozoan parasites.

We thus conclude that additional water purification procedures are necessary if the health risk posed by this organism is to be effectively eliminated. These findings may provide further insight into the possible sources of Cryptosporidium and Giardia in the natural environment, and stress the potential risk associated with the use of waters for recreational and agricultural purposes.

\section{References}

BAUMGARTNER J, MURCOTT S and EZZATI (2007) Reconsidering 'appropriate technology': the effects of operating conditions on the bacterial removal performance of two household drinking water filter systems. Environ. Res. Lett. 2 1-6.

BRANDONISIO O, PORTINCASA F, TORCHETTI G, LACARPIA N, RIZZI A, FUMAROLA L, DONADIO F, and CARNIMEO D (2000) Giardia and Cryptosporidium in water: evaluation of two concentration methods and occurrence in wastewater. Parassitologia 42 205-209.

CACCIÒ SM, DE GIACOMO M and POZIO E (2002) Sequence analysis of the $\beta$-giardin gene and development of a polymerase chain reaction-restriction fragment length polymorphism assay to 
genotype Giardia duodenalis cysts from human faecal samples. Int. J. Parasitol. 32 1023-1030.

CACCIÒ SM, DE GIACOMO M, AULICINO FA and POZIO E (2003) Giardia cysts in wastewater treatment plants in Italy. Appl. Environ. Microbiol. 69(6) 3393-3398.

CASSON LW, SORBER CA, SYKORA JL, GAVAGHAN PD, SHAPIRO MA and JAKUBOWSKI W (1990) Giardia in wastewatereffect of treatment. Water. Pollut. Control Fed. Res. J. 62 670-675.

CASTRO-HERMIDA JA, GARCÍA-PRESEDO I, ALMEIDA A, CONZÁLEZ-WARLETA, DA COSTA JMC and MEZO M (2008) Contribution of treated wastewater to the contamination of recreational river areas with Cryptosporidium spp. and Giardia duedenalis. Water Res. 42 3528-3538.

CLANCY JL, MARSHALL MM, HARGY TM and KORICH DG (2004) Susceptibility of fivestrains of Cryptosporidium parvum oocysts to ultraviolet light disinfection. J. AWWA 96 (3) 84-93.

CLARK ME, GIDDINGS CW and MCEVOY JM (2008) Sources of Cryptosporidium in a rural watershed. International Workshop on Opportunistic Protists, May 2008, Boston MA.

DWAF (DEPARTMENT OF WATER AFFAIRS and FORESTRY, SOUTH AFRICA) (1996) South African Water Quality Guidelines (2nd edn.) Vol. 2: Domestic Use. Pretoria, South Africa. 86-87.

GERICKE M, BATEMAN B, RAPHOLO F, MASHAKANA J, MAJARAY V, HILNER CA and KFIR R (1995) Occurrence of Protozoan Parasites in South African Source and Treated Water. WRC Report No. 451/1/95. Water Research Commission, Pretoria, South Africa.

INSULANDER M, LEBBAD M, STENSTRÖM TA and SVENUNGSSON B (2005) An outbreak of cryptosporidiosis associated with exposure to swimming pool water. Scand. J. Infect. Dis. 37 354-60.

JARMEY-SWAN, BAILEY IW and HOWGRAVE-GRAHAM AR (2001) Ubiquity of water-borne pathogens, Cryptosporidium and Giardia in KwaZulu-Natal populations. Water SA 27 (1) 57-64.

JOHNSON DW, PIENIAZEK NJ, GRIFFIN DW, MISENER L and ROSE JB (1995) Development of a PCR protocol for sensitive detection of Cryptosporidium oocysts in water samples. Appl. Environ. Microbiol. 61 3849-3855.

MACKINTOSH G, DELPORT E and MANSFIELD J (2000) Drinking water parasites: monitoring, managment and treatment - South African case study. Presented at WISA 2000, 28 May to 1 June 2000, Sun City, South Africa.

MAHDY AKM, SURIN J, LIM YAL and AL-MEKHLAFI MSH (2007) Current situation of Giardia and Cryptosporidium among Orang Asli (arboriginal) communities in Pahang, Malaysia. Southeast Asian J. Top. Med. Public Health 38 (suppl. 1) 27-31.

MOMBA MNB and MFENYANA C (2005) Inadequate treatment of wastewater: A source of coliform bacteria in receiving surface water bodies in developing countries - Case study: Eastern Cape Province of South Africa. In: Lehr JH and Keeleey J (eds.) Water Encyclopedia Domestic, Municipality and Industrial Water Supply and Waste Disposal. A.J. Wiley and Sons Inc., New Jersey. 661-667.

MOMBA MNB, OSODE AN and SIBEWU M (2006) The Impact of inadequate wastewater treatment on the receiving water bodies - Case study: Buffalo City and Nkonkobe Municipalities of the Eastern Cape. Water SA 32 (5) 687-692.

MOMBA MNB, MALAKATE VK and THERON J (2006) Abundance of pathogenic Escherichia coli,Salmonella typhimurium and Vibrio cholerae in Nkonkobe drinking water sources. J. Water Health 4 289-296.

MOMBA MNB, ABONGO BO and MWAMBAKANA JN (2008) Prevalence of enterohaemoragic Escherichia coli $\mathrm{O} 157: \mathrm{H} 7$ in drinking water and its predicted impact on diarrhoeic HIV/AIDS patients in the Amathole District, Eastern Cape Province, South Africa. Water SA 34 (3) 365-372.

MOMBA MNB and SIBEWU M (2009) Survival of somatic and F-RNA coliphages in treated wastewater effluents and their impact on viral quality of the receiving water bodies in the Eastern Cape Province. J. Biol. Sci. 9 (7) 648-654.

MURCOTT S (2006) Implementation, critical factors and challenges to scale-up of household drinking water treatment and safe storage systems. Background paper on Household Water Treatment and Safe Storage (HWTS) for the electronic conference hosted by USAID/Hygiene Improvement Project (HIP), 12-22 May, 2006. 39 pp.

PEGRAM GC, ROLLINS N and ESPREY Q (1998) Estimating the cost of diarrhoea and epidemic dysentery in KwaZulu-Natal and South Africa. Water SA 24 11-20.

PENNIL CC, CLARK ME, GIDDINGS CW and MCEVOY JM (2008) Sources of Cryptosporidium in a rural watershed. National Water Quality Conference, Sparks, Nevada.

PRITCHARD M, MKANDAWIRE T, EDMONDSON A, O'NEILL JG AND KULULANGA G (2009) Potential of using plant extracts for purification of shallow well water in Malawi. Phys. Chem. Earth, Parts A/B/C 34 (13-16) 799-805.

REED C, STURBAUM GD, HOOVER PJ and STERLING CR (2001) Cryptosporidium parvum mixed genotypes detected by PCR-Restriction Fragment Length Polymorphism Analysis. Appl. Environ. Microbiol. 427-429.

ROBERTSON LJ, HERMANSEN L and GJERDE BK (2000) Occurrence of Cryptosporidium oocysts and Giardia cysts in sewage in Norway. Appl. Environ. Microbiol. 72 (8) 5297-5303.

ROSE JB, HUFFMAN DE and GENNACCARO A (2002) Risk and control of water-borne cryptosporidiosis. FEMS Microbiol. Rev. 26 113-123.

SPANO FL, PUTIGNANI J, McLAUCHLIN DP, CASEMORE A and CRISANTI A (1997) PCR-RFLP analysis of the Cryptosporidium oocyst wall protein (COWP) gene discriminates between $C$. wrairi and $C$. parvum, and between $C$. parvum isolates of human and animal origin. FEMS Microbiol. Lett. 150 209-217.

STATS SA (2001) Statistics South Africa Census 2001. Republic of South Africa. URL: http://www.nokengmun.co.za/demographics. aspx (Accessed 6 May 2010).

STURBAUM GD, REED C, HOOVER PJ, JOST BH, MARSHALL MM, and STERLING CR (2001) Species-Specific, Nested PCRRestriction Fragment Length Polymorphism Detection of Single Cryptosporidium Parvum Oocysts. Appl. Environ. Microbiol. 67 (6) 2665-2667.

THOMPSON RCA (2000) Giardiasis as a re-emerging infectious disease and its zoonotic potential. Int. J. Parasitol. 30 1259-1267.

US EPA (UNITED STATES ENVIRONMENTAL PROTECTION AGENCY) (2001) Method 1623 - Cryptosporidium and Giardia in water by filtration/IMS/FA. U.S. Environmental Protection Agency Publication No. 821/R-01-025. U.S. Environmental Protection Agency, Washington, DC.

VAN VUUREN L (2009) The state of water in South Africa - Are we heading for a crisis? The Water Wheel 8 (5) 31-33.

VENTER SN (2000) Rapid microbiological monitoring methods: The status quo. IWA The Blue Pages. IWA, London.

XIAO L, SINGH A, LIMOR J, GRACZYK TK, GRADUS S and LAL A (2000) Molecular characterization of Cryptosporidium oocysts in samples of raw surface water and wastewater. Appl. Environ. Microbiol. 67 (3) 1097-1101.

WHO (2004) Guidelines for Drinking-water Quality. Vol 1 ( $3^{\text {rd }}$ edn.) Recommendation. World Health Organization, Geneva. 259-274. 
